\title{
Limited evidence of interactive disturbance and nutrient effects on the diversity of macrobenthic assemblages
}

\author{
Valeska Contardo Jara ${ }^{1,5}$, José Henrique S. Miyamoto ${ }^{2}$, Bernardo A. P. da Gama ${ }^{2}$, \\ Markus Molis $^{3,4, *}$, Martin Wahl ${ }^{3}$, Renato C. Pereira ${ }^{2}$ \\ ${ }^{1}$ Institute of Biology, Animal Systematics and Evolution, Free University of Berlin, Königin-Luise-Straße 1-3, \\ 14195 Berlin, Germany \\ ${ }^{2}$ Departamento de Biologia Marinha, Instituto de Biologia, Universidade Federal Fluminense, CP 100644, \\ CEP 24001-970 Niterói, Rio de Janeiro, Brazil \\ ${ }^{3}$ Leibniz Institute of Marine Sciences, Experimental Ecology, Düsternbrooker Weg 20, 24105 Kiel, Germany \\ ${ }^{4}$ Present address: Biologische Anstalt Helgoland, Alfred Wegener Institute for Polar and Marine Research, Marine Station, \\ Kurpromenade 201, 27498 Helgoland, Germany \\ ${ }^{5}$ Present address: Leibniz Institute for Freshwater Ecology and Inland Fisheries, Müggelseedamm 301, 12587 Berlin, Germany
}

\begin{abstract}
The causes and consequences of the coexistence of a number of species in a given habitat have attracted ecological research for several decades. Numerous theories have been developed in this context, including the 'intermediate disturbance hypothesis' (IDH), but supportive experimental evidence remains scarce and contradictory, leading scientists to propose the existence of an interaction between disturbance and productivity. This study assessed the interactive effects of disturbance and nutrient enrichment at 1 oligotrophic (Arraial do Cabo) and 1 eutrophic (Guanabara Bay) site on the coast of Brazil. At each site, an epibenthic assemblage was allowed to establish on settlement panels (PVC) for 3 mo prior to a 6 mo manipulation phase comprising nutrient enrichment and disturbance (biomass removal). Our results revealed site-specific diversity-driving processes in the absence of disturbance. Nevertheless, diversity and species richness peaked at both sites at some intermediate level of disturbance, corroborating the IDH. Nutrient enrichment increased total species richness and algal species richness in particular, but only at the oligotrophic site. Only here, did nutrient enrichment eliminate the unimodal species richness pattern observed along the disturbance gradient under ambient nutrient concentrations. Such interactive effects of disturbance and productivity on diversity confirm the general predictions of advanced IDH models, e.g. the Kondoh model. The present study indicates that interactive effects of 'bottom-up' and 'top-down' processes may explain more of the variation in community diversity than the separate models of disturbance-diversity and productivity-diversity relationships.
\end{abstract}

KEY WORDS: Intermediate disturbance hypothesis - Species diversity - Nutrient enrichment · 'Bottom-up' · Fouling $\cdot$ Productivity $\cdot$ Species richness $\cdot$ Brazil

- Resale or republication not permitted without written consent of the publisher

\section{INTRODUCTION}

Anthropogenic extinction and invasion of species can greatly affect the number of species that co-occur in a given ecosystem (Lodge 1993, Pimm et al. 1995, Cohen \& Carlton 1998, McCann 2000). Thus, it is becoming increasingly necessary to determine and analyze in detail the factors that affect variation in diversity for different ecosystems, since changes in biodiversity may alter ecosystem processes (Tilman et al. 1996, McGrady-Steed et al. 1997, Hector et al. 1999, Chapin et al. 2000), may affect the resilience of ecosystems to environmental change (e.g. Tilman \& Downing 1994) and may have profound consequences for benefits that humans derive from ecosystems (Costanza et al. 1997, Chapin et al. 2000). 
Settlement dynamics in densely colonized areas (e.g. rocky shores) are a function of the presence and subsequent utilization of limiting resources (e.g. space in epibenthic assemblages) (Sousa 1979a, Dethier 1984, Holt et al. 1995). The subsequent replacement sequence within such an assemblage will depend on the availability of resources as well as the reproductive, competitive and adaptive capacities of the existing consortium of species (Sousa 1984a, Menge \& Sutherland 1987, Wilson \& Tilman 1991).

Disturbance is suggested to be one of the main factors influencing assemblage structure and diversity by introducing limiting resources (Connell 1978, Sousa 2001). Bare substratum is the key limiting resource for benthic fouling assemblages, allowing vegetative growth of adjacent species into open patches and/or propagule-mediated recruitment (Sousa 1984b, Pickett \& White 1985). The trade-off between superior competitive ability and the ability to colonize newly available habitats was suggested to be disturbancemediated and to influence species diversity (e.g. De'ath 2002). Levin \& Paine (1974) and Connell (1978) proposed low diversity in the absence of disturbance and under strong disturbance regimes, due to persistence of either superior competitors or colonizers, respectively, while diversity is expected to be higher at intermediate levels of disturbance, through coexistence of both groups. This straightforward model was thus called 'intermediate disturbance hypothesis' (IDH), and has been tested in marine (Sousa 1979b), freshwater (e.g. Lake et al. 1989) and terrestrial communities (e.g. Molino \& Sabatier 2001). However, the studies conducted to date obtained conflicting results: a variety of diversity patterns along disturbance gradients have been found in a multitude of natural or experimental systems (see Mackey \& Currie 2001, Shea et al. 2004 for reviews). The inconsistencies in these patterns suggest that additional factors interact with and have an influence on diversity-disturbance relationships.

Productivity is considered to be another key factor affecting and regulating diversity (e.g. Worm et al. 2002, Cornwell \& Grubb 2003), and has attracted increasing attention due to worldwide increases in coastal eutrophication derived from human activities (Nixon 1995, Nixon \& Buckley 2002). Productivity and diversity are often unimodally related, such that peak diversity is observed at intermediate productivity levels (Rosenzweig \& Abramsky 1993, Abrams 1995, Kassen et al. 2000, Chase \& Leibold 2002). These observations have been further mathematically elaborated by Kondoh (2001) using a spatial competition model. Non-selective types of disturbances, e.g. randomly located clearings in benthic assemblages, should benefit superior colonizers (i.e. inferior competitors) while they disfavor superior competitors by reducing competitive exclusion. In con- trast, higher productivity, which increases colonization rate, encourages inferior colonizers (superior competitors) while discouraging inferior competitors by increasing the risk of competitive exclusion (Kondoh 2001). Furthermore, the model predicts that the separate effects of disturbance on the competitive outcome of multi-species dynamics will mostly result in humpshaped disturbance-diversity relationships, while the interactive effects of diversity and productivity will shift the diversity peak towards higher disturbance regimes with increasing levels of productivity.

Evidence supporting these models is scant. Wilson \& Tilman (2002) reported a decrease in species richness from old fields with increased nutrients under all disturbance regimes, while similar results were obtained for plankton assemblages by Beisner (2001). Hillebrand (2003) described decreasing species richness with growing intensity of grazing (i.e. disturbance) and a slight increase in species numbers with productivity, but no hump-shaped pattern in freshwater periphyton. However, Kassen et al. (2004) observed peaks of bacterial diversity at intermediate disturbance that move towards increased disturbance with increasing productivity, as predicted by the Kondoh model.

Because the effects of productivity and disturbance on diversity have generally been analyzed separately, their interactions in nature have remained elusive. We experimentally tested Kondoh's model by manipulating disturbance regimes ( 7 frequencies) and nutrient supply (ambient, low and high nutrient enrichment) and measuring their effects on species richness, diversity $\left(H^{\prime}\right)$ and species composition of fouling assemblages at 1 oligotrophic and 1 eutrophic site. We examined (1) which of the 2 factors influence diversity in a given system, (2) whether diversity peaks along the chosen disturbance gradient, (3) whether the level of productivity affects diversity-disturbance relationships, and (4) how strong, if any, these interactive effects are.

\section{MATERIALS AND METHODS}

Study sites. Identical experiments were conducted at 2 sites within the coastline of the Rio de Janeiro state, SE Brazil, SW Atlantic. One study site, Arraial do Cabo, was located on the Island of Cabo Frio $\left(42^{\circ} 00^{\prime} \mathrm{W}\right.$, $\left.23^{\circ} 44^{\prime} \mathrm{S}\right)$, the second site was inside Guanabara Bay on the Island of Mocanguê $\left(43^{\circ} 08^{\prime} \mathrm{W}, 22^{\circ} 02^{\prime} \mathrm{S}\right)$.

At Arraial do Cabo, the oligothrophic site, the experiment was set up in a sheltered bay in the northern part of the granite-based island. During the study period, sea-surface water temperature was $18^{\circ} \mathrm{C}( \pm 2.0 \mathrm{SD})$. This relatively cold water temperature for a tropical site was due to upwelling events that had been observed year-round, with peaking frequency be- 
tween October and April, resulting in a minimum temperature of $14^{\circ} \mathrm{C}$ (Valentin 1974, Castro \& Miranda 1998). Ambient nutrient levels for this fully marine site (salinity $36.0 \pm 0.2)$ were $10 \mu \mathrm{g} \mathrm{l}^{-1}( \pm 4.0)$ for nitrates and $10 \mu \mathrm{g} \mathrm{l}^{-1}( \pm 3.0)$ for phosphates. The sea floor consists of sand beds, interspersed by banks of gneissgranite rock, extending parallel to the shore. The benthic community at this site is dominated by seaweeds. Clear zonation patterns were observed, with Sargassum sp. being highest on the shore, followed by Dictyota sp. and Geodia corticostylifera on the sandy ground. Major consumers at the site were the fishes Balistes vetula, Diplodus argenteus and Holocentrus ascensionis (Ferreira et al. 2001).

The second, eutrophic site, was located $50 \mathrm{~m}$ away from the active area of a naval base on the coast of the Island of Mocanguê. The muddy shores of Guanabara Bay host a species-poor benthic community composed of ascidians, polychaetes and seaweeds (mainly Ulva fasciata and Enteromorpha compressa) (Taouil \& Yoneshigue-Valentin 2002). At Guanabara Bay, mean ambient nitrate and phosphate levels of $37( \pm 15)$ and $52 \mu \mathrm{g} \mathrm{l}^{-1}( \pm 20)$, respectively, were recorded during the study period. These high nutrient levels are a result of sewage transported by $>30$ rivers from the city of Rio de Janeiro into Guanabara Bay. The water from this site (mean salinity $34.5 \pm 2.5$ ), exchanges with the open Atlantic ocean only through a narrow inlet $(1.6 \mathrm{~km})$ during semidiurnal tides (Mayr et al. 1989).

We chose these 2 sites to test for disturbancenutrient interactions under contrasting conditions of background nutrient supply and productivity. Our rationale was that to cover the full range of nutrient supply or productivity in nature we needed to combine small-scale experimental and large-scale environmental gradients. Arraial do Cabo had low, and Guanabara Bay relatively high levels of nutrient supply and productivity.

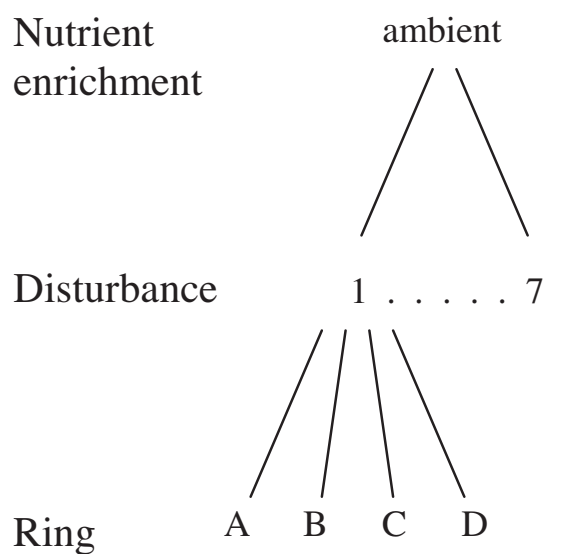

Experimental design and set-up. Experiments were arranged in a 3-factorial split-plot design, with 'disturbance' (fixed, 7 levels), fully crossed with 'nutrients' (fixed, 3 levels) treatments (Fig. 1). Plots were split to eliminate interference arising from different nutrient treatments. Thus, 7 panels, each exposed to 1 of the 7 disturbance treatments, were grouped by attaching them randomly to 1 PVC ring (= block). The same nutrient level was allocated to all panels of a single block. A total of 12 blocks was used, where 4 randomly selected blocks were exposed to either ambient, low or high enriched nutrient treatments. Thus blocks (random, 12 levels) were nested within nutrients (Fig. 1). To assess block $\times$ disturbance interactions, 2 additional panels were randomly allocated to single rings for within-block replication of 2 disturbance treatments (Underwood 1997, p. 391-400).

At Arraial do Cabo, 12 white PVC rings $(600 \mathrm{~mm}$ diameter, $250 \mathrm{~mm}$ high, $2 \mathrm{~mm}$ thick) were positioned along a line of buoys $150 \mathrm{~m}$ from the shore at a depth of $50 \mathrm{~cm}$; rings at Guanabara Bay were fixed at the same depth in 2 parallel rows with 6 rings per row ca. $5 \mathrm{~m}$ away from a quay wall. At both sites, the minimum distance between 2 adjacent rings was 3 times the ring diameter, i.e. $\geq 1.8 \mathrm{~m}$, representing 3 times the distance at which fertilizer effects were no longer detectable in pilot studies. Using cable ties, 9 white PVC settlement panels $(150 \times 150 \times 2 \mathrm{~mm})$ were fixed to the inside of each ring, with the roughened (sandpaper grain-type $200 \mathrm{~mm}$ ) surface (i.e. the area to be sampled) facing towards the center of the rings. All panels within single rings were evenly spaced by $6 \mathrm{~cm}$ gaps in which fertilizer-filled plastic bags (mesh $1 \mathrm{~mm}$ ) or control bags were fixed (see next subsection).

Disturbance and nutrient-enrichment treatments. The panels were incubated on 1 August 2003, and were then left untreated for the next 3 mo to allow establishment of an epibenthic assemblage. Distur-

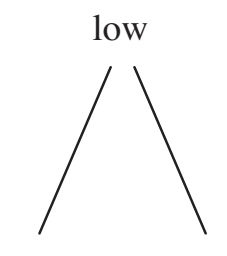

$1 \ldots 7$

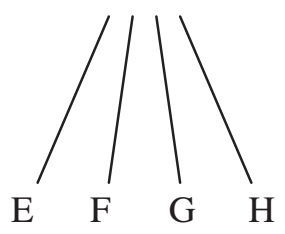

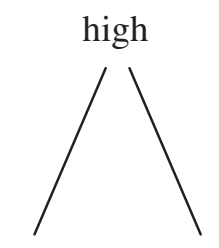
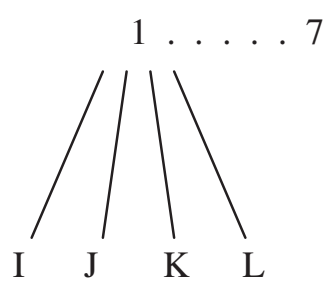

Fig. 1. Experimental design of 3-factorial split-plot ANOVA: 7 levels of disturbance (see 'Material and methods' for details) were fully crossed with 3 levels of nutrient enrichment (ambient, low, and high) and rings (= Blocks A to L) were nested within nutrient enrichments 
bance and nutrient manipulations were from 1 November 2003 to 30 April 2004, i.e. when the experiment was terminated. Nutrient levels were manipulated by a controlled-release fertilizer (Plantacote Pluss M6) incorporated into polyurethane beads (2 to $4 \mathrm{~mm}$ diameter), which has been shown to enhance ambient nutrient levels in the field (Worm et al. 2000). Based on pilot studies, 3 nutrient treatments were applied. Treatment 1 (ambient): bags were filled with cleaned seashells instead of fertilizer beads to control for treatment artifacts caused by the presence of filled fertilizer bags; Treatments 2 (low) and 3 (high): ambient nitrate concentrations were increased by 150 and $200 \%$, respectively. The amount of fertilizer needed to achieve the respective enrichments was determined during pilot studies. To ensure effective fertilizer release-rates, nutrient beads were exchanged monthly. Prior to such exchange, the new fertilizer beads were watered for $3 \mathrm{~d}$. At fortnightly intervals, the nitrate and phosphate concentrations in front of the settlement panels were monitored and, when necessary, the nutrient concentrations adjusted to the desired level.

According to Grime (1977), disturbance is associated with the destruction of biomass. In the present study, a single disturbance event comprised non-selective removal of biomass from 2 randomly chosen circular areas, each representing $7.5 \%$ of the total panel area. We applied 7 disturbance frequencies. Disturbance events within each frequency level were evenly spaced over time, ranging from no disturbance (= control) over $2,3,4,5,7$ to 12 times during the 6 mo manipulation period. A new random area was selected for each repeated disturbance treatment, with previously undisturbed and cleared areas having equal chances of being disturbed.

Water analyses. Using a plastic syringe $(60 \mathrm{ml})$, water samples were taken at a distance of $5 \mathrm{~cm}$ in front of each panel at fortnightly intervals. At Arraial do Cabo (oligotrophic site), 2 syringes were filled per panel, resulting in $1080 \mathrm{ml}$ total sample volume per ring; at Guanabara Bay (eutrophic site) 1 syringe was filled per panel, resulting in $540 \mathrm{ml}$ total sample per ring. Samples from each panel were immediately filtered (47 $\mu \mathrm{m}$, GFF Whatman) and the filters were then stored in a cooler at $0^{\circ} \mathrm{C}$ in the field for later chlorophyll a ( $\mathrm{chl} a)$ analysis in the laboratory (stored at $-20^{\circ} \mathrm{C}$ ), using the methods of Jeffrey \& Humphrey (1975). Filtered water was collected from each ring, and two $50 \mathrm{ml}$ aliquots were used to measure nitrate and phosphate concentrations (Grasshoff et al. 1983). The nutrient concentrations of the water samples did not reflect the increases recorded during the pilot study. The discrepancy very probably resulted from destruction of nutrient gradients in front of the panels when the rings were moved during the multiple subsampling (during the pilot study, only single samples were taken from isolated fertilizer bags). Nevertheless, nutrient effects were evident in the biological data at Arraial do Cabo (e.g. a significant increase in total cover of autrotrophs), and experimental manipulation of the nutrients is the only logical explanation for this.

Community sampling. For each panel, percentage cover was estimated for each species to the nearest $5 \%$ on 1 November 2003 and 30 April 2004, i.e. prior to and at the end of the manipulation period. Species identification was carried out in the field, and was in some instances only possible to genus level. Species with $<5 \%$ cover were recorded as $1 \%$, i.e. present. All estimates used in the analysis were done by eye. Microscopic examination (a stereo microscope; $12 \times$ magnification), of randomly chosen subsamples confirmed that no macrobenthic settlers were omitted by such estimates. To avoid edge-effects a $1 \mathrm{~cm}$ wide band along the edge of each panel was excluded from sampling. Because of the multilayered structure of the species assemblages, estimates of total percent cover exceeded $100 \%$. On 1 November, the percentage cover of all species was estimated from 3 randomly selected panels on each ring to calculate species richness and the Shannon-Wiener-index, $H^{\prime}$ (hereafter diversity), together with mean percent cover.

Statistical analysis. Percentage data used directly for statistical analysis were arcsine-transformed prior to the calculations. The species composition of undisturbed assemblages at both sites was compared with the non-parametric analysis of similarity (ANOSIM, Primer Software Version 5.0) based on multi-species data. The analysis uses the difference between ranked values of Bray-Curtis measures of similarity in abundance and types of organisms among replicates between and within samples (Austen \& Warwick 1989). Homogeneity of variances was tested by Cochran's $C$-test. Differences for data that showed heteroscedasticity after transformation were significant at $\mathrm{p} \leq 0.01$. Student's $t$-tests compared species richness and diversity of undisturbed panels at an early and late successional stage, i.e. prior to and at the end of manipulations, respectively. The effects of disturbance and nutrient enrichment on diversity and species richness were analyzed separately for each site in a 3-factorial ANOVA. Where disturbance $\times$ ring interaction terms were non-significant at the $\mathrm{p} \leq 0.25$ level, $F$-ratios were reanalyzed using $M S_{\text {residual }}$ as the denominator to minimize Type II errors. Ryans $Q$ was used for post-hoc tests of 3-factorial ANOVAs. To test whether nutrient enrichment differentially affected diversity patterns along disturbance gradients, a general linear model (GLM) for separate regressions was performed with data sets from each site. Data sets from each site were grouped 
by disturbance treatments and analyzed in a mixedmodel 2-factorial ANOVA, using Tukey's HSD as the post-hoc test. Moreover, data were analyzed by linear and quadratic polynomial regression analysis to assess diversity patterns along the disturbance gradient.

\section{RESULTS}

Species composition differed significantly between the epibenthic communities of the 2 sites (ANOSIM: $\mathrm{R}=1, \mathrm{p}=0.002$ ).

The effects of disturbance were not dependent on the level of nutrient enhancement for any response variable when tested by ANOVA (Table 1). However, when patterns were analyzed, a significant nutrient $\times$ disturbance interaction was detected for species richness at Arraial do Cabo, using GLM for separate regressions (Table 2). When nutrient $\times$ disturbance interactions were absent, the main effects of nutrient enhancement and disturbance frequency were considered separately.

Table 1. Results of ANOVA examining effects of nutrient enrichment and disturbance on diversity $\left(H^{\prime}\right)$, species richness $(S)$, and species richness of macroalgae $(S(A))$ for an oligotrophic site (Arraial do Cabo) and an eutrophic site (Guanabara Bay). Numbers in parentheses: df of error terms; Block: PVC ring; nd: no data (low number of recruiting algae)

\begin{tabular}{|lcccccccc|}
\hline Source & df & \multicolumn{2}{c}{$H^{\prime}$} & \multicolumn{2}{c}{$S$} & \multicolumn{2}{c}{$S(A)$} \\
& & $F$ & $\mathrm{p}$ & $F$ & $\mathrm{p}$ & $F$ & $\mathrm{p}$ \\
\hline Arraial do Cabo & & & & & & & \\
Nutrient supply (N) & $2(9)$ & 0.76 & 0.496 & 5.11 & 0.033 & 6.81 & 0.016 \\
Disturbance (D) & $6(54)$ & 3.04 & 0.012 & 4.77 & 0.001 & 0.91 & 0.494 \\
Block (B) & $9(24)$ & 0.67 & 0.729 & 1.24 & 0.321 & 1.81 & 0.118 \\
$\mathrm{~N} \times \mathrm{D}$ & $12(54)$ & 0.71 & 0.731 & 1.11 & 0.372 & 0.68 & 0.760 \\
$\mathrm{D} \times \mathrm{B}$ & $24(54)$ & 0.74 & 0.819 & 0.59 & 0.945 & 0.94 & 0.583 \\
Guanabara Bay & & & & & & & \\
Nutrient supply (N) & $2(9)$ & 3.26 & 0.086 & 1.34 & 0.309 & nd & nd \\
Disturbance (D) & $6(54)$ & 4.57 & 0.001 & 9.41 & $<0.001$ & nd & nd \\
Block (B) & $9(54)$ & 0.92 & 0.522 & 1.28 & 0.298 & nd & nd \\
N $\times$ D & $12(54)$ & 0.89 & 0.564 & 1.51 & 0.151 & nd & nd \\
D $\times$ B & $24(54)$ & 1.06 & 0.455 & 0.81 & 0.749 & nd & nd \\
\hline
\end{tabular}

Table 2. Results of general linear model (GLM) for separate regressions, comparing patterns of response variables along disturbance gradient for different levels of nutrient enrichmentat the 2 sites

\begin{tabular}{|c|c|c|c|c|c|c|c|}
\hline \multirow[t]{2}{*}{ Source } & \multirow{2}{*}{ df } & \multicolumn{3}{|c|}{ Arraial do Cabo } & \multicolumn{3}{|c|}{ Guanabara Bay } \\
\hline & & MS & $F$ & $\mathrm{p}$ & MS & $F$ & $\mathrm{p}$ \\
\hline \multicolumn{8}{|l|}{ Diversity } \\
\hline Nutrient $\times$ disturbance & 3 & 0.014 & 0.27 & 0.847 & 0.02 & 0.40 & 0.751 \\
\hline Nutrient & 2 & 0.012 & 0.23 & 0.797 & 0.00 & 0.04 & 0.963 \\
\hline Residual & 102 & 0.053 & & & 0.07 & & \\
\hline \multicolumn{8}{|l|}{ Species richness } \\
\hline Nutrient $\times$ disturbance & 3 & 11.30 & 1.49 & $<0.001$ & 2.48 & 0.74 & 0.533 \\
\hline Nutrient & 2 & 42.93 & 5.66 & 0.230 & 0.94 & 0.28 & 0.757 \\
\hline Residual & 102 & 7.58 & & & 3.37 & & \\
\hline
\end{tabular}

\section{Guanabara Bay (eutrophic site)}

Community structure

A total of 23 species was recorded (Table 3). The abundance of some species changed significantly along the disturbance gradient (Fig. 2A), but was not affected by nutrient enrichment. The bryozoan Bugula neritina dominated all communities, although its abundance decreased by a significant $49 \%$ between undisturbed and most frequently disturbed communities (ANOVA, $F_{6,54}=3.12, \mathrm{p}=0.01$ ). Likewise, the abundance of the bryozoan Schizoporella errata decreased significantly by $21 \%$ along the disturbance gradient (ANOVA, $\left.F_{6,54}=3.47, \mathrm{p}=0.005\right)$. Five species (Didennum candidum, D. ligulum, Bryopsis pennata, Codium taylorii and Enteromorpha linza) were present on all but the most frequently disturbed panels. The opposite pattern was displayed by the green algae Cladophora vagabunda, which colonized exclusively the most disturbed panels (i.e. those disturbed 7 and 12 times). Disturbance had a positive effect on abundance of the hydroid Obelia dichotoma and the colonial ascidian Diplosoma listerianum, which increased in cover by 46 and 55\%, respectively, between undisturbed and most frequently disturbed communities.

\section{Effects on diversity and species richness}

Diversity and total species richness were not significantly affected by nutrient enrichment, nor was there a significant nutrient $\times$ disturbance interaction (Table 1). However, diversity was significantly affected by disturbance (Table 1), being 19\% higher in communities that had been disturbed 4 times than in undisturbed and most frequently disturbed communities (Fig. 3). Diversity-disturbance patterns were not dependent on the level of nutrient enrichment (GLM for separate regressions: $\mathrm{R}_{\text {corr }}^{2}=0.005, F_{5,102}=1.10, \mathrm{p}=$ 0.366 , Table 2). The pattern for diversity along the disturbance gradient displayed a significant hump-shaped relationship that explained $21 \%$ of the variance (Table 4).

Species richness of undisturbed communities decreased by a significant $25 \%$ during the manipulation period, 
Table 3. Species found on panels at end of experiment, representing typical members of macroepibenthic assemblage at each site

\begin{tabular}{|c|c|c|}
\hline Group & Guanabara Bay & Arraial do Cabo \\
\hline Green algae & $\begin{array}{l}\text { Bryopsis pennata } \\
\text { Cladophora vagabunda } \\
\text { Codium taylorii } \\
\text { Enteromorpha linza } \\
\text { Ulva fasciata }\end{array}$ & $\begin{array}{l}\text { Bryopsis pennata } \\
\text { Cladophora vagabunda } \\
\text { Codium spongiosum } \\
\text { Enteromorpha linza } \\
\text { Ulva fasciata }\end{array}$ \\
\hline Red algae & & $\begin{array}{l}\text { Jania capillacea } \\
\text { Laurencia sp. } \\
\text { Polysiphonia sp. } \\
\text { Spyridia filamentosa }\end{array}$ \\
\hline Brown algae & & $\begin{array}{l}\text { Dictyota menstrualis } \\
\text { Feldmania irregularis } \\
\text { Hinksia mitchelliae }\end{array}$ \\
\hline Sponges & & $\begin{array}{l}\text { Dysidae etheria } \\
\text { Mycale mikrosigmatosa } \\
\text { Mycale angulosa }\end{array}$ \\
\hline Hydroids & Obelia dichotoma & $\begin{array}{l}\text { Obelia dichotoma } \\
\text { Ectopleura dumortierii } \\
\text { Campanularidae } 1 \\
\text { Campanularidae } 2\end{array}$ \\
\hline Polychaetes & $\begin{array}{l}\text { Branchiomma nigromaculata } \\
\text { Hydroides sp. } \\
\text { Polydora sp. }\end{array}$ & $\begin{array}{l}\text { Hydroides sp. } \\
\text { Polydora sp. }\end{array}$ \\
\hline Crustaceans & $\begin{array}{l}\text { Balanus sp. } 1 \\
\text { Balanus sp. } 2\end{array}$ & $\begin{array}{l}\text { Balanus trigonus } \\
\text { Megabalanus sp. }\end{array}$ \\
\hline Bivalves & Ostrea equestris & $\begin{array}{l}\text { Perna perna } \\
\text { Pinctada imbricate }\end{array}$ \\
\hline Ascidians & $\begin{array}{l}\text { Botryllus niger } \\
\text { Botryllus giganteum } \\
\text { Didemnum candidum } \\
\text { Didemnum ligulum } \\
\text { Diplosoma listerianum } \\
\text { Eusynstyela sp. } \\
\text { Styela plicata }\end{array}$ & $\begin{array}{l}\text { Botryllus niger } \\
\text { Didemnum candidum } \\
\text { Didemnum granulatum } \\
\text { Symplegma rubra } \\
\text { Trididemnum obriculatum }\end{array}$ \\
\hline Bryozoans & $\begin{array}{l}\text { Bugula neritina } \\
\text { Bugula turrita } \\
\text { Membranipora membranacea } \\
\text { Schizoporella errata }\end{array}$ & $\begin{array}{l}\text { Bugula neritina } \\
\text { Bugula turrita } \\
\text { Membranipora membranacea } \\
\text { Schizoporella errata }\end{array}$ \\
\hline
\end{tabular}

i.e. after 3 and after 9 mo of succession (Student's $t$-test, $t=13.29, \mathrm{p}<0.001$ ). Neither the effects of nutrient enrichment, nor a nutrient $\times$ disturbance interaction significantly affected species richness (Table 1). In contrast, disturbance had a significant effect on the number of species colonizing the panels (Table 1). The number of algal taxa growing on settlement plates at Guanabara Bay was too small to permit a test of disturbance effects on algal species richness for this site. Species richness-disturbance patterns were not dependent on the level of nutrient enrichment (GLM for separate regressions: $\mathrm{R}_{\text {corr }}^{2}=-0.008, F_{5 ; 102}=0.82, \mathrm{p}=0.539$, Table 2). On average, $35 \%$ more species were encountered on panels that had been disturbed an intermediate number of times (i.e. 3, 4 and 5 times) than on undisturbed and most frequently disturbed panels (Fig. 4). A significant unimodal relationship between species richness and disturbance explained $36 \%$ of the variance (Table 4 ).

\section{Arraial do Cabo (oligotrophic site)}

\section{Community structure}

A total of 34 species was encountered on the panels (Table 3 ). The abundance of some species changed significantly along the disturbance gradient, but was not affected by nutrient enrich-

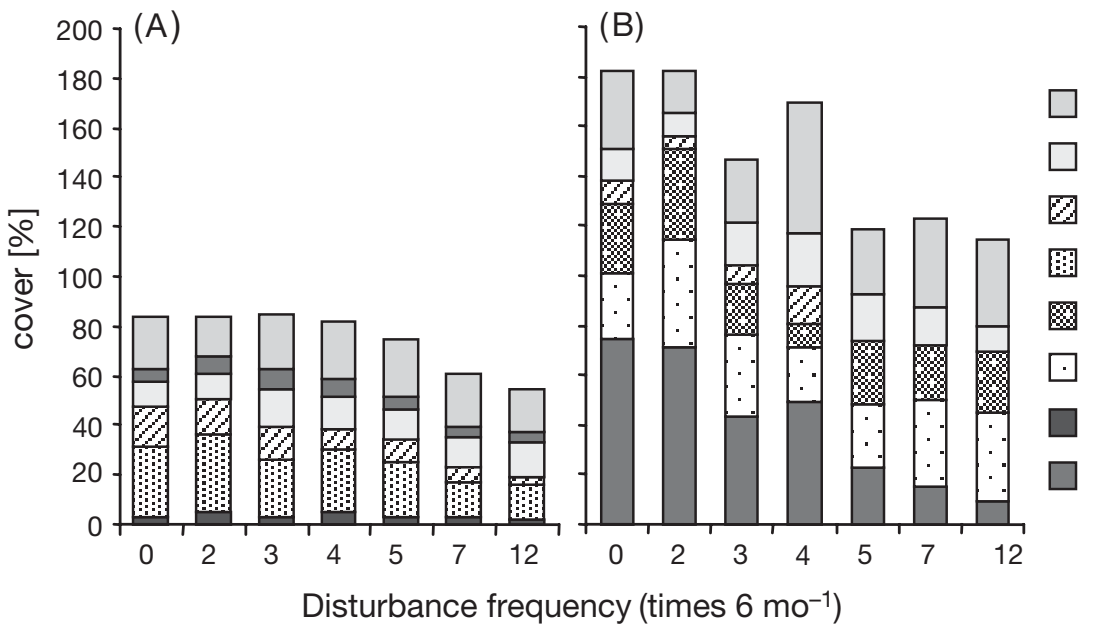

Invertebrates

Obelia dichotoma

Schizoporella errata

Bugula neritina

Rhodophyceae

Phaeophyceae

Chlorophyceae

Balanidae
Fig. 2. Mean abundance of selected species and taxonomic groups on panels exposed to different disturbance frequencies at (A) Guanabara Bay and (B) Arraial do Cabo, pooled for all nutrient treatments 


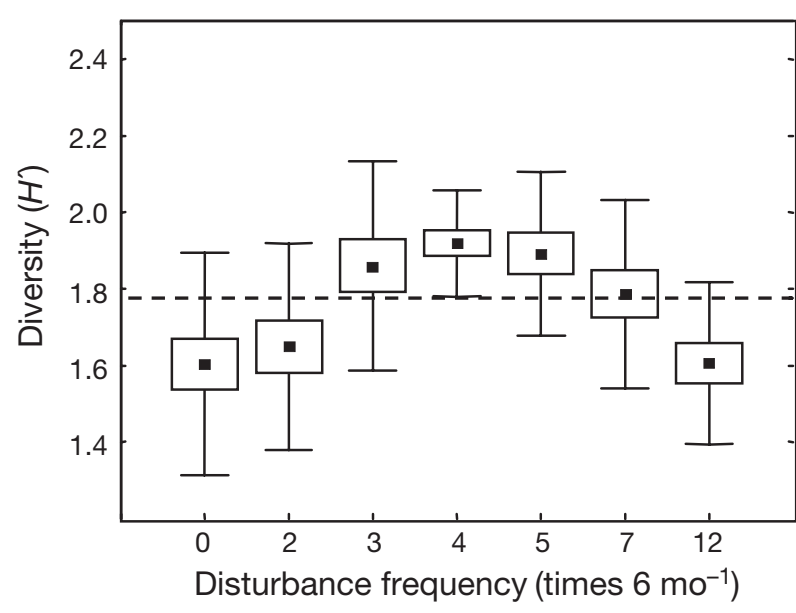

Fig. 3. Diversity (Shannon-Wiener index, $H^{\prime}$ ) at eutrophic site Guanabara Bay along disturbance gradient $(0$ disturbance = control), pooled for all nutrient treatments. Data are means (data points) $\pm \mathrm{SE}$ (boxes) and $\pm \mathrm{SD}$ (whiskers). Dashed line indicates diversity prior to manipulations. Note discontinuous abscissa

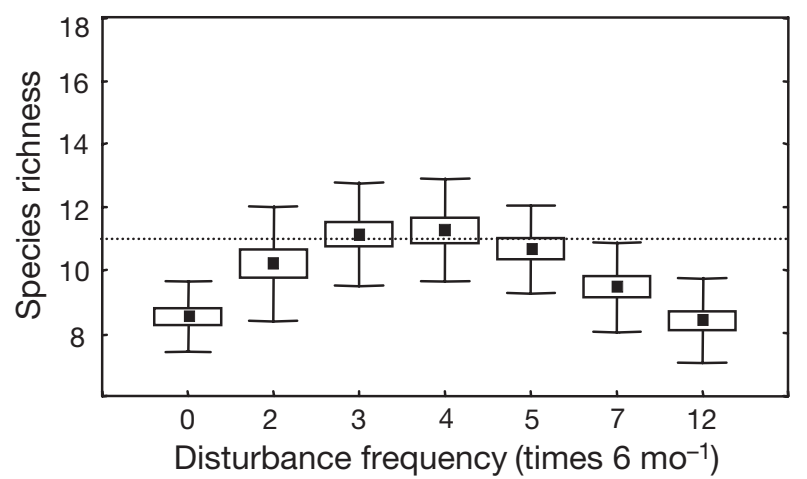

Fig. 4. Species richness at Guanabara Bay along disturbance gradient, pooled for all nutrient treatments. Dashed line indicates richness prior to manipulations. Note discontinuous abscissa. Further details as for Fig. 3

ment. Barnacles dominated the undisturbed and twicedisturbed communities, with up to $75 \%$ abundance. Barnacle abundance decreased significantly (ANOVA, $F_{6,54}=12.85, \mathrm{p}<0.001$ ) with increasing disturbance frequency and was 7 times lower on the most fre-

Table 4. Results of quadratic regression analysis for diversity and species richness along disturbance gradient of both sites. Quadratic model: $y=b_{0}+b_{1} \times$ $x+b_{2} \times x^{2}$

\begin{tabular}{|lccccccc|}
\hline Source & $\mathrm{r}^{2}$ & $\mathrm{df}$ & $F$ & $\mathrm{p}$ & $b_{0}$ & $b_{1}$ & $b_{2}$ \\
\hline Guanabara Bay & & & & & & & \\
$\begin{array}{l}\text { Diversity } \\
\text { Species richness }\end{array}$ & 0.209 & 105 & 13.91 & $<0.001$ & 1.89 & 0.41 & -0.05 \\
Arraial do Cabo & 105 & 29.82 & $<0.001$ & 5.97 & 2.52 & -0.31 \\
$\begin{array}{l}\text { Diversity } \\
\text { Species richness }\end{array}$ & 0.092 & 105 & 5.32 & 0.006 & 1.78 & 0.16 & -0.02 \\
& 0.158 & 105 & 9.89 & $<0.001$ & 15.12 & 1.21 & -0.21 \\
\hline
\end{tabular}

quently disturbed panels than on undisturbed panels (Fig. 2B). Abundance of the bryozoan Schizoporella errata increased in a non-significant trend by $62 \%$ between undisturbed and 4 times-disturbed communities, but this species was missing from all communities that had been disturbed $>4$ times. The hydroid Obelia dichotoma was most abundant in communities that had been disturbed 4 times. Brown algae cover increased by a non-significant $26 \%$ between undisturbed and most frequently disturbed communities.

\section{Effects on diversity and species richness}

Diversity of the undisturbed communities increased by a significant $42 \%$ during the manipulation period, i.e. after 3 and 9 mo succession (Student's $t$-test, $t=$ 12.88, $\mathrm{p}<0.001)$. Diversity was not affected by nutrient enrichment (Table 1). Furthermore, we did not detect a significant interaction between nutrient enrichment and disturbance, but diversity was significantly changed by disturbance (Table 1). Diversity was $13 \%$ higher in communities disturbed 3 times, compared to the undisturbed and most frequently disturbed communities (Fig. 5), resulting in a significant unimodal diversity-disturbance relationship (Table 4). Diversity-disturbance patterns were not dependent on the level of nutrient enrichment (GLM for separate regressions: $\mathrm{R}_{\text {corr }}^{2}=-0.016, F_{5,102}=0.67, \mathrm{p}=0.647$, Table 2).

Total species richness of the undisturbed communities increased by a significant $192 \%$ during the manipulation period, i.e. after 3 and 9 mo succession (Student's $t$-test, $t=29.07, \mathrm{p}<0.001$ ). Total species richness and macroalgal species richness were significantly affected by nutrient enrichment (Table 1). Total and algal species richness increased monotonically with nutrient enrichment by 21 and $80 \%$, respectively, between communities exposed to ambient nutrient levels and to highest nutrient enrichment (Fig. 6). There was no significant interaction between nutrient enrichment and disturbance treatments (Table 1), but disturbance significantly affected species richness (Table 1). Communities that had been disturbed 3 times contained on average a significant $31 \%$ more species than most disturbed communities, and (on average) a non-significant $6 \%$ more species than undisturbed panels (Fig. 7), resulting in a unimodal pattern of species richness along the disturbance gradient (Table 4). Species richness patterns along the disturbance gradient were dependent on the level of nutrient enrichment (GLM for separate regressions: $\mathrm{R}_{\text {corr }}^{2}=$ $0.23 F_{5,102}=7.29, \mathrm{p}=0.023$, Table 2). 


\section{DISCUSSION}

This study revealed that the observed diversitydisturbance patterns matched the predictions of the 'intermediate disturbance hypothesis' (IDH) for 2 distinct tropical macrobenthic communities, i.e. maximum diversity was found at some intermediate level of disturbance frequency. The predicted hump-shaped diversity curve was observed at all levels of experimental nutrient enrichment. Species richness exhibited a similar hump-shaped pattern across the disturbance gradient at the eutrophic site, and was unaffected by nutrient enrichment. In contrast, nutrient enrichment smoothed the hump-shaped curve for species richness versus disturbance at the oligotrophic site.

According to Connell (1978), unimodal patterns of diversity along disturbance gradients require (1) competitive exclusion in the absence of disturbance, (2) harsh environmental conditions under severe disturbance regimes that can be tolerated by only a few species, and (3) release of resources by a disturbance, which can be taken advantage of by species already present at the site. All 3 prerequisites of the IDH seem to be fulfilled in the present study for the macrobenthic community at the eutrophic site (Guanabara Bay): (1) The decrease in diversity and species richness between undisturbed communities prior to ( 3 mo of succession) and at the end of (9 mo of succession) the manipulation period, strongly indicates a competition-driven community succession. The observed loss of 9 species between both dates suggests interference competition as the diversity-reducing driver. Undisturbed communities were dominated by 2 bryozoan species (Bugula neritina and Schizoporella errata), of which the latter is known to inhibit the growth of adjacent species (Sutherland \& Karlson 1977). (2) Diversity and species richness were lower under the most severe disturbance treatment than at intermediate disturbance levels. This loss in diversity can be best explained by the harshness of the disturbance regime, generated by 1.8 times biomass removal of the entire panel area $(15 \%$ disturbed panel area $\times 12$ disturbance events) under the most frequent disturbance treatment. Such unstable environmental conditions were tolerated by species with high colonizing abilities e.g. Diplosoma listerianum (Naranjo et al. 1996), Styela plicata (Naranjo et al. 1996, Mayer-Pinto \& Junqueira 2003), and Obelia dichotoma, but reduced the performance of both competitively superior bryozoan species. Competitively inferior species covered disturbance-generated patches within 1 to 2 wk by lateral growth (J. H. S. Miyamoto pers obs.), occupying open space permanently before larval-driven recruitment could occur. (3) Maximum diversity and species richness at intermediate disturbance regimes were due to the coexistence of efficient colonizers (e.g. D. listerianum) and superior competitors (e.g. Schizoporella errata), indicating that disturbance released resources (i.e. open space: Sousa 1979b), for inferior competitors
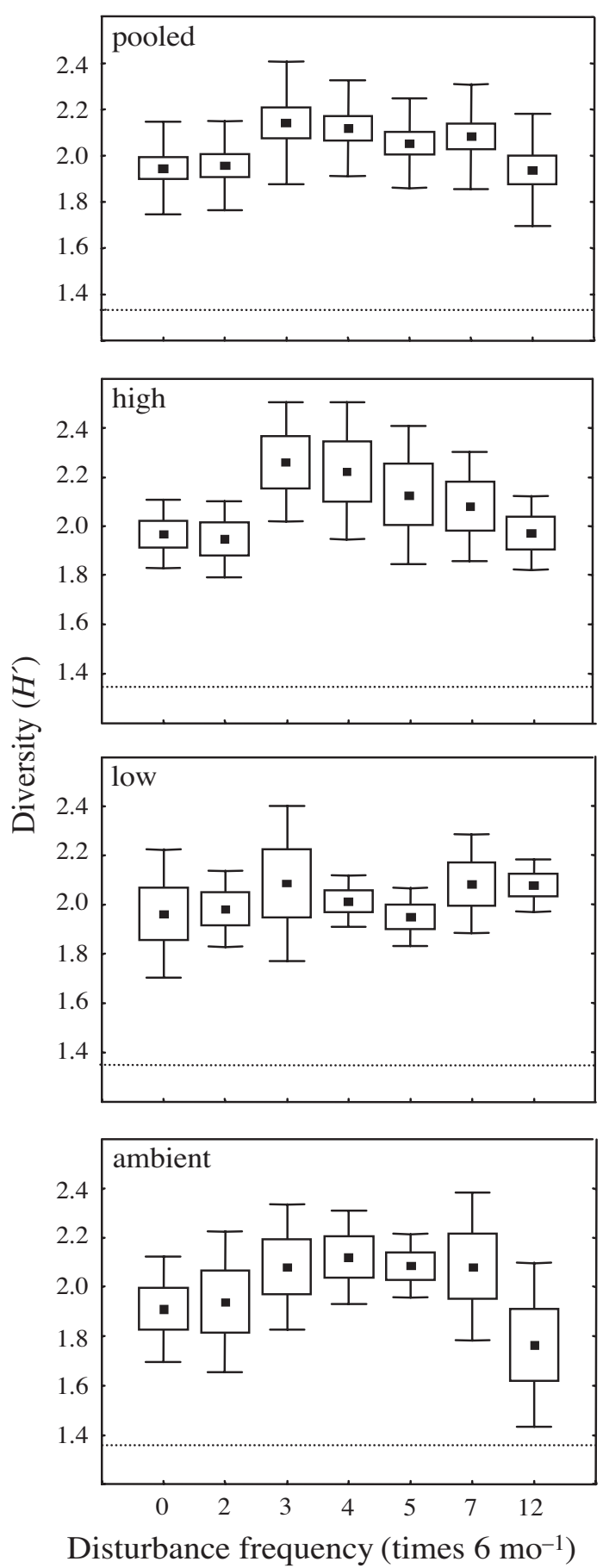

Fig. 5. Species diversity at Arraial do Cabo along disturbance gradient, pooled for all nutrient treatments and nutrient enrichments (ambient low, high). Note discontinuous abscissa. Further details as for Fig. 3 


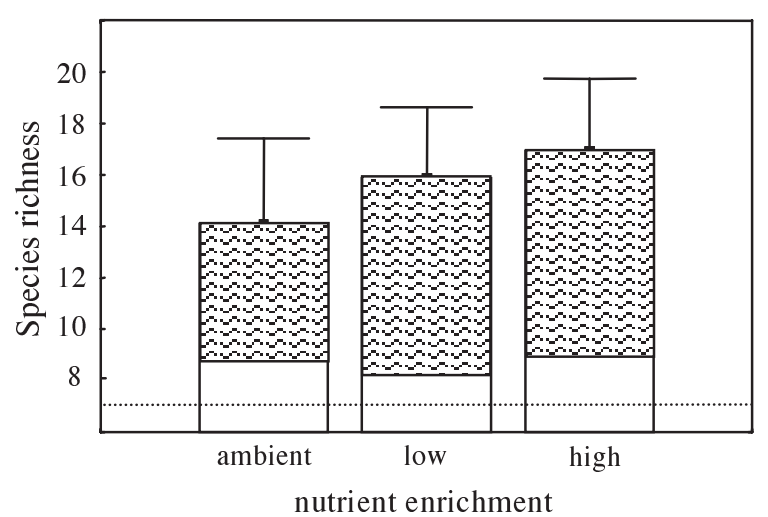

Fig. 6. Mean (+SD) species richness at Arraial do Cabo along gradient of nutrient enrichment (ambient, low, high). Dashed line indicates richness prior to manipulations. Note discontinuous abscissa. White bars: invertebrates; hatched bars: algae

without eliminating superior competitors. Our data support theoretical studies (e.g. Kondoh 2001, Roxburgh et al. 2004, Shea et al. 2004) that assume tradeoffs between colonizing and competitive species as a major driving mechanism for species coexistence. As a result, unimodal diversity-disturbance relationships were observed for the assemblages from Guanabara Bay. Besides competition, other factors such as selective consumption may affect diversity patterns (e.g. Hillebrand 2003). However, there were only minor, if any, signs of consumption on the panels (B. A. P. da Gama pers. obs.). The only predator which may have consumed organisms in our set-up was the omnivorous fish Kyphosus sectatrix at Arraial do Cabo. However, $K$. sectatrix is known to feed non-selectively on members of fouling assemblages (Pereira et al. 2003), suggesting that diversity patterns would not have been biased by selective consumption patterns.

Competitive species exclusion during succession was not apparent at Arraial do Cabo, indicating that the strength and rate of competition were lower at the oligotrophic than at the eutrophic site. Nevertheless, a unimodal diversity pattern was also observed along the disturbance gradient at Arraial do Cabo, suggesting weak competition as the driving mechanism of this pattern, by reducing evenness (data not shown) and ultimately diversity without eliminating species. Barnacles played a central role in the establishment of this pattern. On the one hand, barnacles persistently dominate undisturbed communities by inhibiting the growth of colonial ascidians and bryozoans (Young \& Gotelli 1988) and resist being overgrown (V. Contardo Jara pers. obs.). On the other hand in our study, barnacles were unable to monopolize the substratum on undisturbed panels during the manipulation phase (i.e. species were not excluded from the assemblage) because barnacle spat falls are highly seasonal (Skinner \& Coutinho 2002) and may not occur during most of the manipulation period.

This study has revealed that unimodal diversitydisturbance relationships can result from different processes, corroborating studies of macrobenthic com-
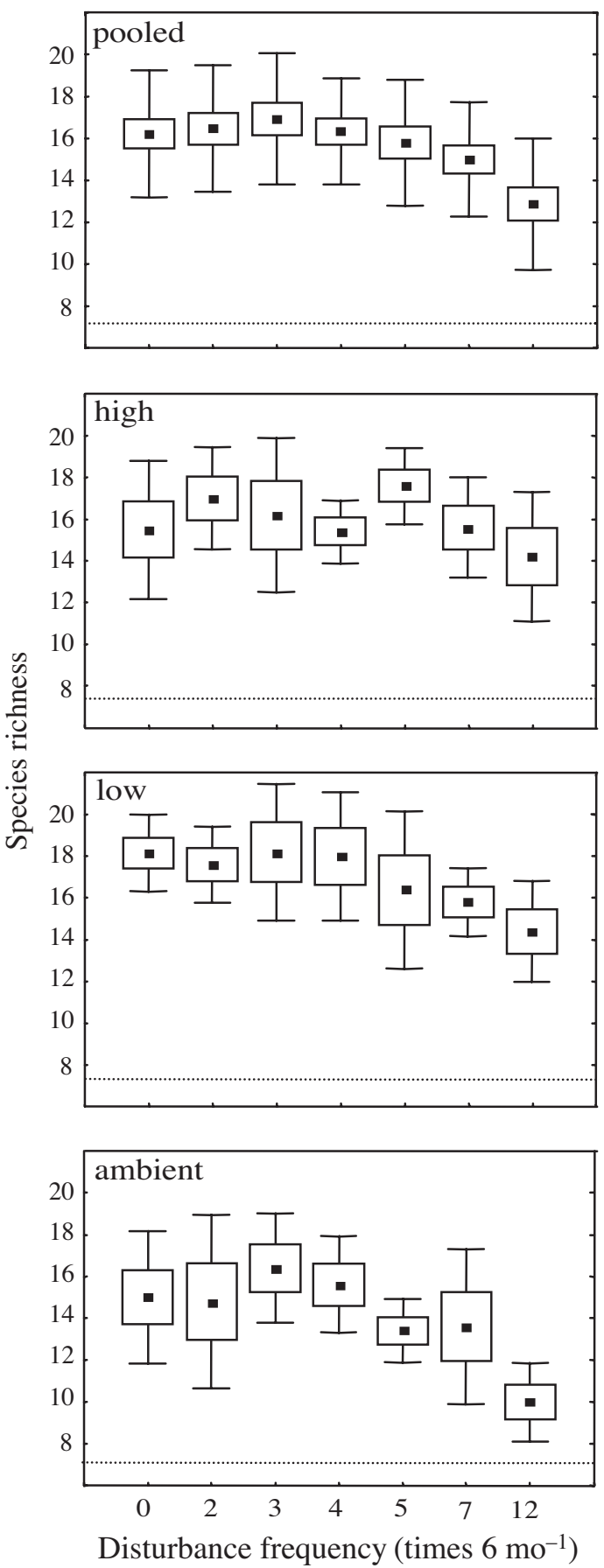

Fig. 7. Species richness at Arraial do Cabo along the disturbance gradient, pooled for all nutrient treatments and for nutrient enrichment (ambient, low, and high). Note discontinuous ordinate. Further details as for Figs. $3 \& 4$ 
munities in the Baltic Sea (Molis et al. 2003). Both the variation in processes generating unimodal diversity patterns as well as the variety in diversity-disturbance relationships themselves (Mackey \& Currie 2001) indicate that disturbance alone may not predict community diversity sufficiently well.

Besides disturbance, productivity may control the diversity and stability of communities (Worm \& Duffy 2003). In our study, species richness decreased on undisturbed panels during the course of succession at the eutrophic site, but increased at the oligotrophic site. Such opposing patterns may reflect bottom-up effects, although differences in species composition between the 2 sites may confound comparison of these patterns. Experimental support that nutrient and food supply can affect community diversity comes from mussel beds (Menge et al. 1997, 1999), marine macroalgal communities (Lotze et al. 2000), and microbenthic assemblages (Hillebrand et al. 2000).

Several models have combined diversity-disturbance relationships with bottom-up processes (e.g. recruitment [Menge and Sutherland 1987] or productivity [Huston 1979, Kondoh 2001]), predicting that interactive effects with (e.g.) productivity cause a variety of patterns in the diversity-disturbance relationship. According to Kondoh (2001), maximum diversity along a disturbance gradient will shift from low to high disturbance as productivity levels increase. Our study did not support the predictions of Kondoh's model for a community that developed in eutrophic conditions, since diversity peaked irrespective of productivity level at intermediate levels of disturbance, i.e. we did not detect interactive disturbanceproductivity effects. In contrast, interactive disturbance-productivity effects on species richness were detected at the oligotrophic site, but these only partly conformed to the predicted patterns of the Kondoh model. At ambient nutrient concentrations, species richness declined with increasing disturbance, as suggested by Kondoh's model, but disturbance did not generate a unimodal pattern, nor did species richness increase along the disturbance gradient at higher nutrient levels as predicted by the Kondoh model. This discrepancy between the model and our data was mainly due to an almost unchanged number of species at all nutrient levels in the absence of disturbance. To our knowledge, only Worm et al. (2002) have experimentally tested the Kondoh model, using consumers and nutrient supply. They reported that consumer effects on diversity depended on nutrient levels. Peak diversity shifted towards higher levels of nutrient supply in the presence of consumers. However, their study combined the results of 2 experiments conducted at different sites and times, thereby limiting the comparability of the data because of confounding factors (e.g. site-specific successional dynamics or interaction webs). Consequently, the results of Worm et al. (2002) may be less realistic than those of the present study, which tested for interactive effects of nutrient enrichment (using the same fertilizer as Worm et al. 2002) and disturbance within 1 type of community.

Several factors could explain the discrepancy in diversity-disturbance patterns between Kondoh's model and our data. (1) The manipulation of nutrients in our study may have affected only the colonization rate of the autotrophic part of the community, while Kondoh's model is based on changes in productivity that would alter the colonization rate of all species. Enhanced levels of food for heterotrophs or additional larval supply (e.g. of competitive superior barnacles) could have resulted in reduced species numbers in undisturbed communities through competitive exclusion, and hence in a unimodal diversity-disturbance relationship as predicted by Kondoh (2001). (2) Algal species richness increased monotonically with increasing nutrient enrichment. Either additional nutrients do not cause competitive exclusion in the algal assemblage of Arraial do Cabo, or the maximum nutrient concentrations used were still too low to result in competitive exclusion. Since the range of productivity and disturbance levels required by the Kondoh model to generate the predicted community responses are unknown, the model cannot be rejected based on the data of this study. (3) Our experiment may not have been conducted for a sufficiently long period of time. A longer manipulation period would be necessary to reveal whether undisturbed communities at Arraial do Cabo display competition-driven succession. The fact that diversity patterns along the disturbance gradient depended on nutrient levels only at the oligotrophic site suggests that the natural state of productivity of systems may be an important factor for affecting the applicability of the Kondoh model. However, conclusions as to the efficacy of this model cannot be drawn, since our experiments did not manipulate productivity in such a way that the colonization rate of all species was enhanced. The result of the present study indicate that interactive effects of 'bottom-up' and 'top-down' processes may explain more of the variation in community diversity than separate models of disturbance-diversity and productivity-diversity relationships.

Acknowledgements. The comments of 2 anonymous reviewers and S. Roxburgh greatly improved an earlier version of the manuscript. We gratefully acknowledge funding by Foundation Mercator to M.W., B.A.P.G. and R.C.P. thank CAPES and CNPq for a ProDoc and a Productivity fellowship, respectively. Thanks to A. T. Souza, M. I. Ilarri, B. L. Antunes, T. F. Porto, H. Contardo, R. Coutinho (IEAPM, Arraial do Cabo), L. N. Silva Jr (BNRJ, Guanabara Bay) and others for 
their inestimable support during field work at both sites. We thank J. C. Creed for reviewing an early draft of this manuscript. Gratis provision of fertilizer by Aglucon, Düsseldorf, Germany, is greatfully acknowledged. This work was performed as part of the international student training and scientific research project GAME (Global Approach by Modular Experiments).

\section{LITERATURE CITED}

Abrams PA (1995) Monotonic or unimodal diversityproductivity gradients: What does competition theory predict? Ecology 76:2019-2027

Austen MC, Warwick RM (1989) Comparison of univariate and multivariate aspects of estuarine meiobenthic community structure. Estuar Coast Shelf Sci 29:23-42

Beisner BE (2001) Plankton community structure in fluctuating environments and the role of productivity. Oikos 95: 496-510

Castro BM, Miranda LB (1998) Physical oceanography of the western Atlantic continental shelf located between $4^{\circ} \mathrm{N}$ and $34^{\circ} \mathrm{S}$. In: Robinson AR, Brink KH (eds) The sea, Vol 11. John Wiley \& Sons, New York, p 209-251

Chapin FS, Zavaleta ES, Eviner VT, Naylor RL and 8 others (2000) Consequences of changing biodiversity. Nature 405:234-242

Chase JM, Leibold MA (2002) Spatial scale dictates the productivity-biodiversity relationship. Nature 416:427-430

Cohen AN, Carlton JT (1998) Accelerating invasion rate in a highly invaded estuary. Science 279:555-558

Connell JH (1978) Diversity in tropical rain forests and coral reefs. Science 199:1302-1309

Cornwell WK, Grubb PJ (2003) Regional and local patterns in plant species richness with respect to resource availability. Oikos 100:417-428

Costanza R, d'Arge R, de Groot R, Farber S and 9 others (1997) The value of the world's ecosystem services and natural capital. Nature 387:253-260

De'ath RG (2002) Predicting invertebrate diversity from disturbance regimes in forest streams. Oikos 97:18-30

Dethier M (1984) Disturbance and recovery in intertidal pools: maintenance of mosaic patterns. Ecol Monogr 54:99-118

Ferreira CEL, Arruda JEG, Coutinho R (2001) Community structure of fishes and habitat complexity on a tropical rocky shore. Environ Biol Fish 61:353-369

Grasshoff K, Ehrhardt M, Kremling K (1983) Methods of seawater analysis, 2nd edn. Verlag Chemie, Weinheim

Grime J (1977) Evidence for the existence of three primary strategies in plants and its relevance to ecological and evolutionary theory. Am Nat 111:1169-1194

Hector A, Schmid B, Beierkuhnlein C, Caldeira MC (1999) Plant diversity and productivity experiments in European grasslands. Science 286:1123-1127

Hillebrand $\mathrm{H}$ (2003) Opposing effects of grazing and nutrients on diversity. Oikos 100:592-600

Hillebrand H, Worm B, Lotze HK (2000) Marine microbenthic community structure regulated by nitrogen loading and grazing pressure. Mar Ecol Prog Ser 204:27-38

Holt TJ, Jones DR, Hawkins SJ, Hartnoll RG (1995) The sensitivity of marine communities to man-induced change-a scoping report. CCW Contract Sci Rep 65. Countryside Council for Wales, Bangor

Huston MA (1979) A general hypothesis of species diversity. Am Nat 113:81-101

Jeffrey SW, Humphrey GF (1975) New spectrophotometric equations for determining chlorophylls $a, b, c 1$ and $c 2$ in higher plants, algae, and natural phytoplankton. Biochem Physiol Pflanz (BPP) 167:191-194

Kassen R, Buckling A, Bell G, Rainey PB (2000) Diversity peaks at intermediate productivity in laboratory microcosms. Nature 406:508-512

Kassen R, Llewellyn M, Rainey PB (2004) Ecological constraints on diversification in a model adaptive radiation. Nature 431:984-988

Kondoh M (2001) Unifying the relationships of species richness to productivity and disturbance. Proc R Soc Lond B 268:269-271

Lake PS, Doeg TJ, Marchant R (1989) Effects of multiple disturbance on macroinvertebrate communities in the Acheron River, Victoria. Aust J Ecol 14:507-514

Levin SA, Paine RT (1974) Disturbance, patch formation, and community structure. Proc Natl Acad Sci USA 71: $2744-2747$

Lodge (1993) Biological invasions: lessons for ecology. Trends Ecol Evol 8:133-137

Lotze HK, Worm B, Sommer U (2000) Propagule banks, herbivory and nutrient supply control population development and dominance patterns in macroalgal blooms. Oikos 89:46-58

Mackey RL, Currie DJ (2001) The diversity-disturbance relationship: is it generally strong and peaked? Ecology 82: 3479-3492

Mayer-Pinto M, Junqueira AOR (2003) Effects of organic pollution on the initial development of fouling communities in a tropical bay, Brazil. Mar Pollut Bull 46:1495-503

Mayr LM, Tenenbaum DR, Villac MC, Paranhos R, Nogueira CR, Bonecker SLC, Bonecker ACT (1989) Hydrobiological characterization of Guanabara Bay. In: Magoon O, Neves C (eds) Coastlines of Brazil. American Society of Civil Engineers, New York, p 124-138

McCann KS (2000) The diversity-stability debate. Nature 405:228-233

McGrady-Steed J, Harris PM, Morin PJ (1997) Biodiversity regulates ecosystem predictability. Nature 390:162-165

Menge BA, Sutherland JP (1987) Community regulation: variation in disturbance, competition, and predation in relation to environmental stress and recruitment. Am Nat 130:730-757

Menge BA, Daley BA, Wheeler PA, Dahlhoff E, Sanford E, Strub T (1997) Benthic-pelagic links and rocky shore intertidal communities: bottom-up effects on top-down control? Proc Natl Acad Sci USA 94:14530-14535

Menge BA, Daley BA, Lubchenco J, Sanford E, Dahlhoff E, Halpin PM, Hudson G, Burnaford JL (1999) Top-down and bottom-up regulation of New Zealand rocky intertidal communities. Ecol Monogr 69:297-330

Molino JF, Sabatier D (2001) Tree diversity in tropical rain forests: a validation of the intermediate disturbance hypothesis. Science 294:1702-1704

Molis M, Lenz M, Wahl M (2003) Radiation effects along a UV-B gradient on species composition and diversity of a shallow-water macrobenthic community in the western Baltic. Mar Ecol Prog Ser 263:113-125

Naranjo SA, Carballo JL, García-Gomes JC (1996) Effects of environmental stress on ascidian populations in Algeciras Bay (southern Spain). Mar Ecol Prog Ser 144:119-131

Nixon SW (1995) Coastal marine eutrophication: A definition, social causes, and future concerns. Ophelia 41:199-219

Nixon SW, Buckley BA (2002) 'A strikingly rich zone' - nutrient enrichment and secondary production in coastal marine ecosystems. Estuaries 25:782-796

Pereira RC, da Gama BAP, Teixeira VL, Yoneshigue-Valentin Y (2003) Ecological roles of natural products of the Brazilian red seaweed Laurencia obtusa. Braz J Biol 63:665-672 
Pickett STA, White PS (1985) Patch dynamics: a synthesis. In: Pickett STA, White PS (eds) The ecology of natural disturbance and patch dynamics, Academic Press, New York, p 371-384

Pimm SL, Russell GJ, Gittleman JL, Brooks TM (1995) The future of biodiversity. Science 269:347-350

Rosenzweig ML, Abramsky Z (1993) How are diversity and productivity related? In: Ricklefs RE, Schluter, D (eds) Species diversity in ecological communities, University of Chicago Press, Chicago, IL, p 52-65

Roxburgh SH, Shea K, Wilson JB (2004) The intermediate disturbance hypothesis: patch dynamics and mechanisms of species coexistence. Ecology 85:359-371

Shea K, Roxburgh SH, Rauschert SJ (2004) Moving from pattern to process: coexistence mechanisms under intermediate disturbance regimes. Ecol Lett 7:491-508

Skinner LF, Coutinho R (2002) Preliminary results on settlement of the barnacles Tetraclita stalactifera and Chthamalus bisinuatus on a Brazilian tropical rocky shore under upwelling conditions. Invertebr Reprod Dev 41: 151-156

Sousa WP (1979a) Experimental investigations of disturbance and ecological succession in a rocky intertidal algal community. Ecol Monogr 49:227-254

Sousa WP (1979b) Disturbance in marine intertidal boulder fields: the nonequilibrium maintenance of species diversity. Ecology 60:1225-1239

Sousa WP (1984a) Intertidal mosaics - patch size, propagule availability, and spatially-variable patterns of succession. Ecology 65:1918-1935

Sousa WP (1984b) The role of disturbance in natural communities. Annu Rev Ecol Syst 15:353-391

Sousa WP (2001) Natural disturbance and the dynamics of marine benthic communities. In: Bertness MD, Gaines SD, Hay ME (eds) Marine community ecology. Sinauer Associates, Sunderland, MA, p 85-130

Editorial responsibility: Howard I. Browman (Associate Editor-in-Chief), Storebø, Norway
Sutherland JP, Karlson RH (1977) Development and stability of the fouling community at Beaufort, North Carolina. Ecol Monogr 47:425-446

Taouil A, Yoneshigue-Valentin Y (2002) alterações na composição florística das algas da praia de Boa viagem (Niterói, RJ). Rev Bras Bot 25:405-412

Tilman D, Downing JA (1994) Biodiversity and stability in grasslands. Nature 367:363-365

Tilman D, Wedin D, Knops J (1996) Productivity and stability influenced by biodiversity in grassland ecosystems. Nature 379:718-720

Underwood, AJ (1997) Experiments in ecology. Their logical design and interpretation using analysis of variance. Cambridge University Press, Cambridge

Valentin JL (1974) O plâncton na ressurgência de Cabo Frio (Brasil). II. Primeiras observações sobre a estrutura física, química e biológica das águas da estação fixa. Publ Inst Pesq Mar Bras 83:1-11

Wilson SD, Tilman D (1991) Interactive effects of fertilization and disturbance on community structure and resource availability in an old field plant community. Oecologia 88: $61-71$

Wilson SD, Tilman D (2002) Quadratic variation in old-field species richness along gradients of disturbance and nitrogen. Ecology 83:492-504

Worm B, Duffy JE (2003) Biodiversity, productivity and stability in real food webs. Trends Ecol Evol 18:628-632

Worm B, Reusch TBH, Lotze HK (2000) In situ nutrient enrichment: methods for marine benthic ecology. Int Rev Gesamten Hydrobiol 85:359-375

Worm B, Lotze HK, Hillebrand H, Sommer U (2002) Consumer versus resource control of species diversity and ecosystem functioning. Nature 417:848-851

Young CM, Gotelli NJ (1988) Larval predation by barnacles: effects on patch colonization in a shallow subtidal community. Ecology 69:624-634

Submitted: April 20, 2005; Accepted: September 1, 2005

Proofs received from author(s): January 10, 2006 